\title{
SKILLS UPDATE
}

BOOK 3

\author{
ILLUSTRATED BY MIKE BOSTOCK
}

Edited by

Sue Smith, Editor,

Community Outlook

Designed by

Hilary Tranter 


\section{(C) Macmillan Magazines Ltd 1994}

All rights reserved. No reproduction, copy or transmission of this publication may be made without written permission.

No paragraph of this publication may be reproduced, copied or transmitted save with written permission or in accordance with the provisions of the Copyright, Design and Patents Act 1988 or under the terms of any licence permitting limited copying issued by the Copyright

Licensing Agency, 33-34 Alfred Place, London WCIE 7DP.

Any person who does any unauthorised act in relation to this publication may be liable to criminal prosecution and civil claims for damages.

First edition 1994

Published by

Macmillan Magazines Ltd

4 Little Essex Street

London WC2R 3LF

Additional material to this book can be downloaded from http://extras.springer.com

ISBN 978-0-333-62296-4 ISBN 978-1-349-13584-4 (eBook)

DOI 10.1007/978-1-349-13584-4 


\section{FOREWORD}

As the move towards care in the community progresses, more and more people require both holistic health care and a wide range of technical nursing procedures in their own homes.

Early hospital discharge, day surgery and out-patient treatments mean that early post-operative care such as pain relief and bowel care is increasingly becoming the responsibility of nurses working in the community.

Skills Update 3, the third collection of articles from the popular series which appears each month in Community Outlook, is intended to give nurses and students an understanding of a range of procedures, such as peritoneal dialysis and tracheostomy care, affecting their patients and clients in the community.

It is not intended to be a first-line teaching series for new skills but, rather, to be used as an update to encourage practitioners to reflect on skills they may have learned some time ago or to provide background information and an overview of technical procedures experienced by patients so that the best holistic care can be given, whatever the patient's environment.

Increasing use of skill mix for the delivery of care to people at home and in residential care means that a wider range of carers need education about the care of people who may previously have received more nursing input - for example, people who have a plaster cast or who need an orthosis.

The Skills Update books may prove useful as aids to those who are teaching non-nurse carers about treatments their relatives or clients are receiving.

It is hoped that the books will be used as a basis for discussion between nurses, students and clinical specialists in hospitals and residential care as well as in general practice and in the community.

Sue Smith

Editor, Community Outlook 


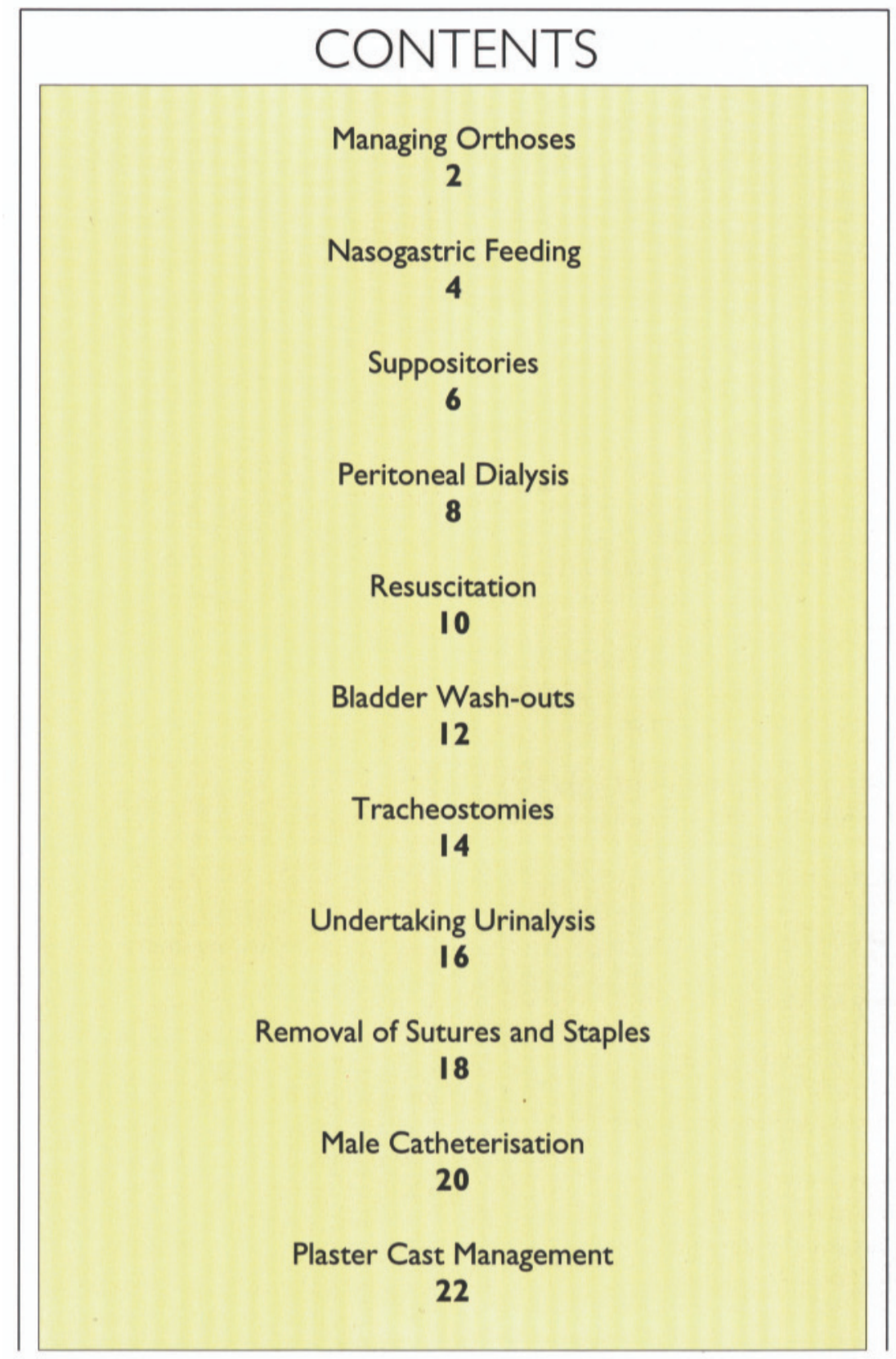

